УДК 556. 16

\title{
В.М. МИШОН (1928-2010) И ЕГО ВКЛАД В РАЗВИТИЕ ГИДРОЛОГИИ (К 90-ЛЕТИЮ СО ДНЯ РОЖДЕНИЯ)
}

\author{
А.Е. Скосарь \\ Воронежский государственный университет, Россия \\ Поступила в редакиию 12 января 2019 г.
}

\begin{abstract}
Аннотация: В День памяти 25 декабря 2018 года сотрудник кафедры природопользования А.Е. Скосарь вспоминает заведующего кафедрой антропогенного ландшафтоведения, профессора, доктора географических наук Виталия Михайловича Мишона.
\end{abstract}

Ключевые слова: профессор, память, ученый.

\section{M. Mishon (1928-2010) and his contribution to the hydrology development (to the 90th anniversary)}

\section{A. E. Skosar}

\begin{abstract}
On the day of memory on December 25, 2018, the employee of the Department of Nature Management A.E. Skosar remembers the Head of the Department of Anthropogenic Landscape Studies, Professor, Doctor of Geographical Sciences Vitaliy Mikhailovich Mishon.
\end{abstract}

Key words: Professor, memory, scientist.

Мишон Виталий Михайлович родился 14 марта 1928 года в г. Полтаве в семье служащих. Вскоре его семья переехала в город Воронеж, где он поступил учиться в среднюю школу. Во время Великой Отечественной войны семья была эвакуирована в Казахскую ССР, где Виталий Мишон продолжил учиться в школе. Его мама работала учителем немецкого языка, а отец на заводе. В 1943 году семья вернулась в город Воронеж, где Виталий Михайлович закончил среднюю школу в 1946 году, и в том же году он поступил учиться на физико-математический факультет Воронежского университета.

В 1951 году В. М. Мишон заканчивает вуз по специальности геофизика и направляется на работу в город Алма-Ата в управление Гидрометеослужбы Казахской ССР. В начале Виталий Михайлович получает должность инженера-гидролога в городе Кустанай, а затем переводится на должность инженера гидролога в само управление. В 1952 году В. М. Мишон был переведен в Цимлян-

(C) Скосарь А.Е., 2019

Материал статьи доступен по лицензии Creative Commons "Attribution" 4.0 скую научно-исследовательскую гидрометеорологическую обсерваторию (ЦНИГО) на должность - инженера гидролога.

На новом месте работы в обязанности старшего инженера входило планирование и организация стационарных наблюдений за гидрологическим режимом водохранилища, а также планирование, организация и личное участие в экспедиционных работах: рейдовых и суточных станциях, проложение поперечных и осевых разрезов водохранилища. Например, зимой 1953-1954 годов совместно с начальником отдела гидрологии Виталий Михайлович выполнил ледово-термическую съемку водохранилища по маршруту город Калач - станица Цимлянская.

По приглашению декана физико-математического факультета ВГУ Н. П. Чеботарева с 1 сентября 1954 года В.М. Мишон в качестве ассистента начал свою трудовую деятельность. Первоначально ему было поручены лекционные курсы по гидрофизике и водно-техническим изысканиям, которые в то время были совершенно не обеспечены учебной литературой. Вот тогда-то молодому преподавателю очень даже пригодились практические 
навыки и знания, полученные на Кустанайской гидрометеорологической станции и в секторе гидрологических прогнозов УГМС КазССР и в ЦНИГО.

За более чем полувековой период работы на географическом факультете, а затем на факультете географии и геоэкологии профессор В. М. Мишон (в этом звании он утвержден в 1989 г.) вел очень большую учебно-методическую и научноисследовательскую работу. Им опубликовано 178 научных работ (около 250 п.л.), из которых 45 работ в центральной печати.

Впервые в СССР он опубликовал учебные пособия «Гидрофизика» и «Практическая гидрофизика» с грифом Минвуза РСФСР и СССР. Эти работы демонстрировались на ВДНХ и ныне широко используются в других вузах нашей страны при подготовке инженеров гидрологов.

Мне удалось прочитать некоторые выдержки из протоколов заседания кафедры по вопросу заслушивания отчета доцента В. М. Мишона, в которых например, м.н.с. С.Д. Дегтяревым был отмечен высокий уровень лекций и лабораторных занятий, проводимых доцентом Мишоном, а так же его успехи в научной работе по теме «Весенний сток». О положительных чертах профессора отзываются многие выпускники факультета. Его ученики до сих пор пишут письма со словами благодарности его семье.

На должность заведующего кафедрой гидрологии суши был избран в 1986 году, а затем на должность заведующего кафедрой антропогенного

Скосарь Анастасия Евгеньевна старший лаборант кафедры природопользования факультета географии, геоэкологии и туризма Воронежского государственного университета, г. Воронеж, т. (473) 266-56-54, E-mail: skosar.nastya@yandex.ru ландшафтоведения в 1991 году. В 2008 году он успешно защитил докторскую диссертацию.

За долголетнюю и плодотворную педагогическую деятельность по подготовке специалистов гидрологов Виталий Михайлович награжден Почетной грамотой ГУГМС (1968 г.) и Почетной грамотой Госкомитета СССР по гидрометеорологии и контролю природной среды (1984 г.). Имел благодарность главы администрации Воронежской области (2001 г.) и Воронежской городской думы (2003 г.). В. М. Мишон участник трех гидрологических съездов (1973, 1986, 2004 гг.). В фондах библиотек вузов РФ, и в том числе зональной научной библиотеке ВГУ можно найти работы ученого. Наиболее значительны среди них: «Снежные ресурсы и местный сток» (Воронеж, 1988), «Практическая геофизика» (Воронеж, 1996), «Поверхостные воды Земли» (Воронеж, 1996), «Река Воронеж и ее бассейн» (Воронеж, 2000).

\section{СПИСОК ЛИТЕРАТУРЫ}

1. Федотов В. И. В. М. Мишон. От инженера гидролога до ученого гидролога / В. И. Федотов // Вестник Воронежского государственного университета. Сер. География. Геоэкология. - 2004. - № 2. - С. 94-97.

\section{REFERENCES}

1. Fedotov V. I., V. M. Mishon. Ot inzhenera gidrologa do uchenogo gidrologa [V.M. Mishon. From a hydrologist engineer to a learned hydrologist]. Vestnik Voronezhskogo gosudarstvennogo universiteta. Ser. Geografiya. Geoekologiya, 2004, No. 2, pp. 94-97.

Skosar Anastasiya Yevgen'yevna

Senior laboratory assistant of the Department of Nature Management of the Faculty of Geography, Geoecology and Tourism, Voronezh State University, Voronezh, t. (473) 266-56-54, E-mail: skosar.nastya@ yandex.ru 